\title{
Response of Two Sweet Sorghum Varieties to Mineral and Bio- Phosphate Fertilization
}

\author{
Nadia Kamel El- Safy ${ }^{1}$
}

\begin{abstract}
Two field experiments were carried out during 2016 and 2017 sumer seasons at the farm of the Agricultural Research Station in Al Sabhia, Alexandria, Egypt, to study the response of two sweet sorghum varieties to three mineral phosphates (calcium mono phosphate $12.5 \mathrm{P}_{2} \mathrm{O}_{5}$ ) levels and two bio- fertilizer (phosphorein) levels on plant growth and its sugar content. The experiment was set up as Split-split plot design in three replications, the main plots were assigned to two sweet sorghum varieties viz., Sugar drip and Mn 4080 and sub plots were occupied with three levels of calcium mono phosphate $(0,100$ and $200 \mathrm{~kg} / \mathrm{fed})$. Phosphorein inoculation (uninoculation, and inoculation) were arranged in the sub-sub plots treatments. The studied plant characters i.e. weight (g), height (cm), stalk diameter, saltk sugar content $(\%)$, leaf weight/plant (g), leaves number, nodes number, leaf length $(\mathrm{cm})$ and leaf width. The results indicated that the effect of mineral and biofertilizer levels had significant effect on yield, yield components and quality traits, varieties differed significantly in all studied characters in both seasons. The highest former traits produced by Mn-4080 and Sugar drip variety. The highest values of plant attributes were obtained by Sugar drip variety with $200 \mathrm{~kg} / \mathrm{fed}$ (super phosphate $12.5 \% \mathrm{P}_{2} \mathrm{O}_{5}$ ) with inoculation by phosphorein.
\end{abstract}

Key words: Sweet sorghum, varieties, mineral, bio fertilization, phosphates

\section{INTRODUCTION}

Sweet sorghum (Sorghum biocolor L.) is planted mainly for syrup, which is called Black honey. It is one of the major sources for syrup production (Osman et. al., 2005 and Mohamed et. al., 2006). It is considered as a C4 plant and Characterized by high stalk and sugar yield (Antonopoulou et al., 2008). Sweet sorghum has taller plant height and possess high biomass (Turhollow et al., 2010). Furthermore, stalk of sweet sorghum produce juice that has high sugar content, which can be used as a main source of ethanol production (Hons et al., 1986 and Reddy and Yang 2005), whereas grain of sorghum can be also used as food, feed and functional food (Sumaryono, 2006). The high sucrose rate of its stalk is not as much as sugarcane and sugar beet plants as well as it has a lower water requirement and drought tolerant, also, its speedy growth rate, early ripeness, high energy value in addition suitable to sub-tropical and temperate region of the world (Rego et al., 2003 and
McLaren et al. 2003). Sorghum grain and juice can be also used to produce other kind of industrial products such as bioplastic, beverages, syrup and also bioethanol. Therefore, this leads to save sugar cane yield for sugar production and reduce the gap between sugar production and consumption which reached 1.10 million $\mathrm{t} /$ year in Egypt (CCSC 2010).

Many characters like green stalk yield, stalk sugar \%, stalk juice extractability and grain yield have been proved as major contributors to its economic superiority (Almodares et al., 2008). Variety development is, however, firstly based on the exploitation of genetic variability of the genotypes with the traits of interest (Makanda et al., 2009)

Productivity of sweet sorghum is influenced by many factors. Variety was one of the most decisions. There is a great difference among sorghum varieties in stalk dimension, yield and its components (Mohamed et al., 2006). Sweet sorghum varieties showed significant differences in leaf area, plant height and diameter, $\%$ of sucrose, purity, juice and syrup extraction, stripped stalk, juice and syrup yields (Ismail et. al., 2007 and Aly et al., 2008).

Different phosphorous fertilizers are considered as one of the main sources to provide with the requirements of plants in arid and semi-arid areas of the world. However, the adverse effects of mineral phosphorous fertilizers have restricted their application, especially in dry regions. A significant increase in yield production of Phaseolus mango was obtained by applying a mixed animal manure and phosphorus solubilizing bacteria fertilizer (Daneshian et al., 2002). Application of phosphorus fertilizer in moderate drought stress had an increase effect on biomass production and water use efficiency. Appropriate soil, P, biofertilization and choice of varieties seriously effaced on crop productivity and soil sustainability the highly values (Benlhabib et al., 2014).

Phosphorous fertilizer application along with phosphorus solubilizing bacteria had a better effect on yield production compared to sole chemical phosphorous fertilizer application (Elkhatib et al.,2009; Gill and Dellon, 1995). The seed inoculation by both Tricoderma and Pseudomonas bacteria have a more efficient effect on nitrogen and phosphorus absorption,

\footnotetext{
${ }^{1}$ Agricultural Research Center, Sugar Crops Research Institute, Alexandria, Egypt

E-Mail : nadia.kamel32@yahoo.com

Received OCTOBR 21, 2018, Accepted November 15, 2018
} 
grain weight, floret in kernel, stalk weight and grain yield of sorghum in a vertisoils. Seed inoculation by Pseudomonas resulted in 6 to $8 \%$ higher yield compared to control while inoculation by Tricoderma recorded 28 to $30 \%$ increase in grain yield. The combined seed inoculation by fungi and bacteria along with application of phosphorus fertilizer result in a better nutrient absorption for plants in poor and infertile soils (Hons et al., 1986). The effect of inoculation by phosphorus sulobilizing bacteria (Pseudomonas type) and mycohrriza fungi on nitrogen and phosphorus absorption and grain yield of sorghum was studied. The inoculation by combination of both microorganisms led to $6-8 \%$ increase in grain yield, $\mathrm{N}$ and $\mathrm{P}$ absorption over the inoculation by sole bacteria and $28-30 \%$ increment over sole fungi inoculation (Reddy and Yang, 2005).

The objective of this investigation was to estimate the growth of two sweet sorghum genotype treated with mineral and bio- fertilization.

\section{MATERIALS AND METHODS}

This investigation was carried out at the farm of AlSabhia Agricultural station in, Alexandria, Egypt, during the two summer seasons of 2016 and 2017.The objective of this work was to evaluate two sweet sorghum varieties under the effect of three levels of calcium super phosphates as mineral fertilizer and two levels from phospherien as bio- fertilizer on plant characteristics of sweet sorghum.

Table 1. Some Physical and chemical properties of the experimental soil in 2016 and 2017 seasons

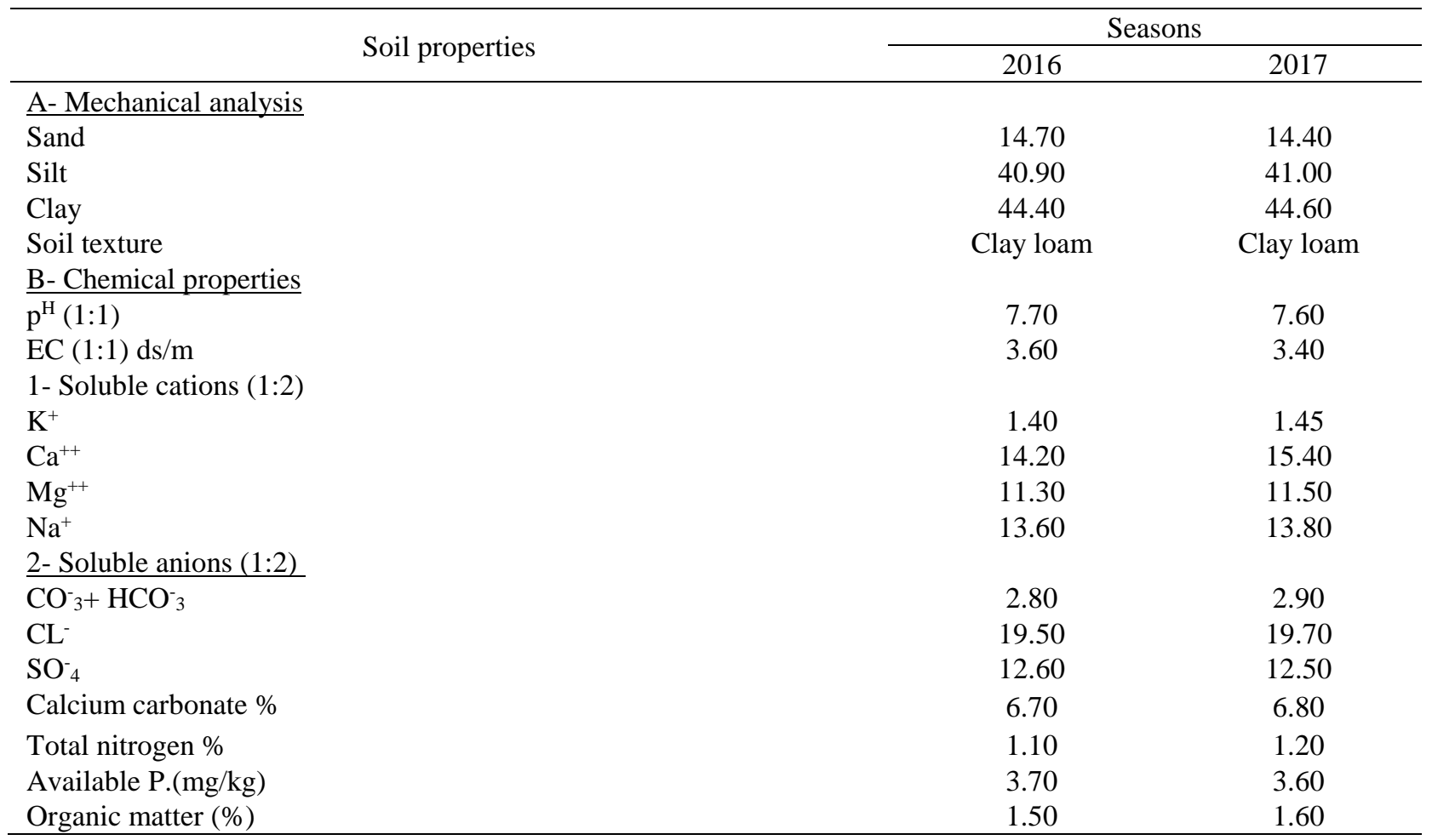

The experiment was set up according to threefactorial (Split-split plot) block design in three replications, with the basic plot size of $10.5 \mathrm{~m}^{2}$, each experimental basic unit included 5 ridges, $60 \mathrm{~cm}$ apart and $3.5 \mathrm{~m}$ long. The main plots were assigned to two sweet sorghum varieties viz., Sugar drip and Mn-4080. The sub plots were occupied with three levels of calcium super phosphate $\left(15.5 \mathrm{P}_{2} \mathrm{O}_{5}\right)$ at the levels of $(0$, 100 and $200 \mathrm{~kg} / \mathrm{fed}$ ) with soil preparation. Bio- fertilizer (Phosphorein inoculation) (without and $1 \mathrm{~kg} / \mathrm{fed}$ ) were arranged in the sub-sub plots with sowing as grain inoculation.

Nitrogen as ammonium nitrate $(33.5 \% \mathrm{~N})$ at the level of $100 \mathrm{~kg} / \mathrm{fed}$ in three equal doses i.e., added at planting, after 21 days from planting and after 35 days from planting. Potassium sulphate $\left(48 \% \mathrm{~K}_{2} \mathrm{O}\right)$ form at the level of $24 \mathrm{~kg}$ was applied in on dose after thinning. Hills thinned at two plants/hill after 21 days from sowing. Other cultural practices such as hoeing, irrigation (surface), etc., were maintained aimed at levels to assure optimum production.

The preceding winter crop was berseem clover (Trifolium alexandrinum L.) in both seasons. Experiments were sown on $10^{\text {th }}$ May and $28^{\text {th }}$ April in the first and second season, respectively. At harvest was at dough to ripe stage on (the end of September) in 2016 and 2017 seasons, respectively. 
Physical and chemical analysis of soil at the experimental site in both seasons of study are presented in Table (1). The soil is a sandy clay loam in both seasons, and defined (Soil Survey Staff, USDA, 1999).

At harvest time a random sample of twenty plants from each sub-sub plot was taken to determine the flowing traits; plant weight $(\mathrm{g})$, plant height $(\mathrm{cm})$, stalk diameter, stalk sugar \%, leaf weight/plant $(\mathrm{g})$, leaves number, nodes number, leaf length, and leaf width.

All obtained data were statistically analyzed according to the technique of analysis of variance (ANOVA) for the split-split plot design according to Gomez and Gomez (1984). Least Significant Difference (LSD) method was used to test the differences between treatment means at 5\% level of probability. Correlations of the traits obtained from the experiment were computed using Costat program. All the statistical analyses were performed by using CoStat V6.4 (2005) for Windows.

\section{RERSULTS AND DISCUSSION}

The results in Tables (2 and 3) revealed the response of two sweet sorghum varieties to three levels of phosphate fertilizer and biofertilizer inoculation and their interaction during 2016 and 2017 seasons.

The results shown in Table (2) indicated that there was significant difference between the two sweet sorghum varieties i.e., Mn 4080 and Sugar drip in plant weight, and plant height in the second and the first seasons, while it had no difference on stalk diameter and stem sugar \% in both seasons. Sugar drip genotype recorded the highest mean values of plant weight (797.2), plant height (234.8 and $217.6 \mathrm{~cm})$ as compared with the other genotype (Mn 4080) which gave the lowest ones in both seasons, respectively. These results are in harmony with those obtained by Murray et al. (2008); Ritter et al. (2008); Srinivas et al. (2009); and Shiringani et al. (2010) who found the variances of these three traits within genotype.

With respect to phosphate fertilizer levels, results in Table (2) revealed that there was significant effect on plant weight $(\mathrm{g})$, plant height $(\mathrm{cm})$, stalk diameter and stem sugar $\%$ in the two seasons, where the rate of calcium super phosphate at $200 \mathrm{~kg} / \mathrm{fed}$ achieved the highest mean values of plant weight (850.0 and $820.8 \mathrm{~g}$ ), plant height (236.8 and $214.6 \mathrm{~cm})$, stalk diameter $(2.4$ and $2.0 \mathrm{~cm})$, and stem sugar $(9.5$ and $12.7 \%)$ as compared with other levels, however control treatment $(0 \mathrm{~kg} / \mathrm{fed})$ gave the lowest values of these traits in both seasons, respectively. The influence of phosphorus is mainly an aggregate of the functions played by nutrients in mitigating negative effects of biotic and abiotic stresses. Plants provided with sufficient amounts of phosphorus are less sensitive to water deficiency, high temperatures and pathogen attacks, and produce high yield (Ma et al. 2006).

Regarding the effect of biofertilizer grain inoculation of sweet sorghum, results in Table (2) showed that biofertilizer affected significantly on pervious characters. Where, using phosphorien as biofertilizer recorded the highest values of plant weight (797.2 and $730.6 \mathrm{~g})$ plant height $(237.7$ and $220.4 \mathrm{~cm})$, stalk diameter (2.5 and $1.9 \mathrm{~cm}$ ), and stem sugar (9.9 and 12.3 $\%$ ) in comparison with uninoculation treatment (without biofertilizer) in the first and the second seasons, respectively. These results agreed with those recorded by Reddy and Yang (2005).

Table (3) report that there was significant difference between the two sweet sorghum varieties i.e., Mn 4080 and Sugar drip in the studied characters like, leaf weight (g) only in the second season, leaves number, node number only in the first season, leaf length, and leaf width while it had no difference on leaf length $(\mathrm{cm})$ in both seasons. Whereas, Mn-4080 genotype recorded the highest mean values of leaf weight (111.2 and $204.2 \mathrm{~g}$ ), and leaves number (12.9 and 13.7), on the other hand, Sugar drip genotype gave the highest value of node number (12.2 and 14.6), and leaf width $(7.3$ and $8.7 \mathrm{~cm})$ in both seasons, respectively.

Also, results in Table (3) show the significant effect of phosphate fertilizer levels on leaf attribute of sweet sorghum, where the application of calcium super phosphate at the rate of $200 \mathrm{~kg} / \mathrm{fed}$ recorded the highest mean values of leaf weight (107.6 and $191.9 \mathrm{~g}$ ), node number (13.1 and 16.2), leaf length (74.5 and $84.7 \mathrm{~cm})$, and leaf width $(7.3$ and $9.2 \mathrm{~cm})$ as compared with others levels, however control treatment $(0 \mathrm{~kg} / \mathrm{fed})$ gave the lowest values of these traits in both seasons, respectively. On the other wise, there was no significant difference on leaves number as affected by levels of mineral phosphorous fertilizer in both seasons. Teshome et al. (2015) agreed with these results and they showed that to increase growth and yield can be use up to 160 $\mathrm{kg} / \mathrm{fed}$.

In respect to biofertilizer effect of sweet sorghum on leaf characters, results in Table (3) show that biofertilizer affected significantly on leaf characters. Where, the highest values of leaf weight (113.5 and $219.5 \mathrm{~g}$ ), node number (13.2 and 14.9), leaf length (72.1 and $79.6 \mathrm{~cm})$, and leaf width $(7.4$ and $8.7 \mathrm{~cm})$ were obtained by grain inoculation by phosphorien as biofertilizer in comparison with uninoculation treatment (without biofertilizer) in both seasons, respectively. 
These results agreed with those recorded by Reddy and Yang (2005).
Also, the interaction among the three factors effect on pervious characters are shown in Table (3).

Table 2. Plant attributes of sweet sorghum varieties as affected by three levels of phosphors and biofertilizer and their interaction in both seasons

\begin{tabular}{|c|c|c|c|c|c|c|c|c|}
\hline \multirow[t]{2}{*}{ Treatments } & \multicolumn{2}{|c|}{ Plant weight $(\mathrm{g})$} & \multicolumn{2}{|c|}{ Plant height $(\mathrm{cm})$} & \multicolumn{2}{|c|}{ Stalk diameter $(\mathrm{cm})$} & \multicolumn{2}{|c|}{ Stalk sugar\% } \\
\hline & 2016 & 2017 & 2016 & 2017 & 2016 & 2017 & 2016 & 2017 \\
\hline \multicolumn{9}{|c|}{ A). Varieties } \\
\hline Mn- 4080 & 672.2 & 663.9 & 230.4 & 207.1 & 1.8 & 1.9 & 9.6 & 11.5 \\
\hline Sugar drip & 797.2 & 691.7 & 234.8 & 217.6 & 2.2 & 1.7 & 9.2 & 11.1 \\
\hline LSD at 0.05 & 99.2 & 43.1 & 15.6 & 9.5 & $\mathrm{~ns}$ & $\mathrm{~ns}$ & $\mathrm{~ns}$ & $\mathrm{~ns}$ \\
\hline \multicolumn{9}{|c|}{ B). Phosphors levels (kg/fed) } \\
\hline 0 (control) & 650.0 & 583.3 & 231.0 & 190.8 & 1.8 & 1.6 & 8.9 & 9.6 \\
\hline 100 & 704.2 & 629.2 & 230.1 & 216.7 & 1.9 & 1.7 & 9.5 & 11.6 \\
\hline 200 & 850.0 & 820.8 & 236.8 & 214.6 & 2.4 & 2.0 & 9.8 & 12.7 \\
\hline LSD at 0.05 & 44.4 & 60.5 & 5.4 & 14.7 & 0.2 & 0.2 & 0.4 & 0.5 \\
\hline \multicolumn{9}{|c|}{ C). Biofertilizer inoculation } \\
\hline without & 672.2 & 625.0 & 227.5 & 194.3 & 1.6 & 1.6 & 9.1 & 10.3 \\
\hline Phosphorein & 797.2 & 730.6 & 237.7 & 220.4 & 2.5 & 1.9 & 9.9 & 12.3 \\
\hline LSD at 0.05 & 60.2 & 38.3 & 6.3 & 7.2 & 0.1 & 0.2 & 0.5 & 0.4 \\
\hline \multicolumn{9}{|c|}{ Interaction } \\
\hline $\mathrm{AB}$ & $*$ & $*$ & $*$ & $*$ & ns & $*$ & $*$ & $*$ \\
\hline $\mathrm{AC}$ & $*$ & $*$ & ns & ns & $\mathrm{ns}$ & $*$ & ns & $*$ \\
\hline $\mathrm{BC}$ & ns & ns & $*$ & $*$ & ns & $\mathrm{ns}$ & ns & $*$ \\
\hline $\mathrm{ABC}$ & ns & * & $*$ & $*$ & $\mathrm{~ns}$ & $\mathrm{~ns}$ & ns & $\mathrm{ns}$ \\
\hline
\end{tabular}

Table 3. Leaf attributes of sweet sorghum varieties as affected by three levels of phosphors and biofertilizer and their interaction in both seasons

\begin{tabular}{|c|c|c|c|c|c|c|c|c|c|c|}
\hline \multirow[t]{2}{*}{ Treatments } & \multicolumn{2}{|c|}{$\begin{array}{c}\text { Fresh Leaf } \\
\text { Weight/plant }(\mathrm{g})\end{array}$} & \multicolumn{2}{|c|}{$\begin{array}{c}\text { Leaves } \\
\text { number/plant }\end{array}$} & \multicolumn{2}{|c|}{$\begin{array}{c}\text { Node } \\
\text { number/plant }\end{array}$} & \multicolumn{2}{|c|}{ Leaf length $(\mathrm{cm})$} & \multicolumn{2}{|c|}{ Leaf width $(\mathrm{cm})$} \\
\hline & 2016 & 2017 & 2016 & 2017 & 2016 & 2017 & 2016 & 2017 & 2016 & 2017 \\
\hline \multicolumn{11}{|c|}{ A). Varieties } \\
\hline Mn 4080 & 111.2 & 204.2 & 15.4 & 17.9 & 11.9 & 14.3 & 70.1 & 80.4 & $6.2 \mathrm{~b}$ & 8.2 \\
\hline Sugar drip & 81.7 & 126.8 & 12.9 & 13.7 & 12.2 & 14.6 & 69.7 & 81.0 & $7.3 \mathrm{a}$ & 8.7 \\
\hline LSD at 0.05 & ns & 52.9 & 1.3 & 1.7 & 0.6 & $\mathrm{~ns}$ & $\mathrm{~ns}$ & $\mathrm{~ns}$ & 1.1 & 0.36 \\
\hline \multicolumn{11}{|c|}{ B). Phosphors levels (kg/fed) } \\
\hline 0 & 84.4 & 151.5 & 14.3 & $16.3^{*}$ & $11.3 \mathrm{~b}$ & $12.9 \mathrm{c}$ & $65.1 \mathrm{c}$ & $79.1 \mathrm{~b}$ & $6.2 \mathrm{c}$ & $7.7 \mathrm{~b}$ \\
\hline 100 & 97.3 & 153.1 & 13.8 & 16.6 & $11.8 \mathrm{~b}$ & $14.3 \mathrm{~b}$ & $70.0 \mathrm{~b}$ & $79.2 \mathrm{~b}$ & $6.7 \mathrm{~b}$ & $8.4 \mathrm{~b}$ \\
\hline 200 & 107.6 & 191.9 & 14.3 & 14.7 & $13.1 \mathrm{a}$ & $16.2 \mathrm{a}$ & $74.5 \mathrm{a}$ & $84.7 \mathrm{a}$ & $7.3 \mathrm{a}$ & $9.2 \mathrm{a}$ \\
\hline LSD at 0.05 & 7.6 & 20.7 & ns & ns & 1.0 & 0.9 & 3.9 & 5.2 & 0.4 & 0.9 \\
\hline \multicolumn{11}{|c|}{ C). Biofertilizer inoculation } \\
\hline without & $79.4 \mathrm{~b}$ & $111.5 \mathrm{~b}$ & 13.9 & 16.3 & $11.0 \mathrm{~b}$ & $13.9 \mathrm{~b}$ & $67.7 \mathrm{~b}$ & 82.3 & $6.2 \mathrm{~b}$ & $8.2 \mathrm{~b}$ \\
\hline Phosphorein & $113.5 \mathrm{a}$ & $219.5 \mathrm{a}$ & 14.4 & 15.4 & $13.2 \mathrm{a}$ & $14.9 \mathrm{a}$ & $72.1 \mathrm{a}$ & 79.6 & $7.4 \mathrm{a}$ & $8.7 \mathrm{a}$ \\
\hline LSD at 0.05 & 8.6 & 15.1 & $\mathrm{~ns}$ & $\mathrm{~ns}$ & 0.6 & 0.8 & 3.7 & 4.7 & 0.5 & 0.4 \\
\hline \multicolumn{11}{|c|}{ Interaction } \\
\hline $\mathrm{AB}$ & * & $*$ & * & ns & ns & ns & * & $\mathrm{ns}$ & $*$ & * \\
\hline $\mathrm{AC}$ & ns & * & * & * & * & ns & ns & ns & * & ns \\
\hline $\mathrm{BC}$ & ns & ns & $*$ & $\mathrm{~ns}$ & ns & $*$ & $\mathrm{~ns}$ & ns & $*$ & $\mathrm{~ns}$ \\
\hline $\mathrm{ABC}$ & ns & ns & $*$ & $\mathrm{~ns}$ & ns & $*$ & ns & ns & $\mathrm{ns}$ & $\mathrm{ns}$ \\
\hline
\end{tabular}


Correlations of eight traits for Mn- 4080 genotype of sweet sorghum were presented in Table (4). Differences were observed in the correlation coefficients in terms of the magnitude and direction under different environments. Plant weight had positively and significantly correlated with plant height $\left(\mathrm{r}=0.510^{*}\right.$ and $0.514^{* *}$ ) in the first and combined season, respectively, node number, sugar $\%$, leaf weight only in the first season, while no significant correlation with plant weight at leaves number, leaf length and leaf width for Mn- 4080 genotype. On the other hand, Plant height had positively and significantly correlated with stalk diameter $\left(\mathrm{r}=0.509^{*}\right)$, node number $\left(0.574^{*}\right)$, sugar $\%$ $\left(0.508^{*}\right)$, leaf weight $\left(0.507^{*}\right)$ only in the second season. Meanwhile, Stalk diameter had positively and significantly correlated with node number $\left(\mathrm{r}=0.700^{*}\right.$, $0.678^{*}$ and $\left.0.555^{* * *}\right)$, sugar $\%\left(0.729^{* * *}, 0.723\right.$ and $\left.0.606^{* * *}\right)$ and leaf weight $\left(0.778^{*}, 0.694^{* *}\right.$ and $\left.0.575^{* * *}\right)$ in the first, second and combined season, and correlated positively with leaf width $\left(0.622^{* * *}\right)$ only in the second season. However, node number of Mn- 4080 genotype had positively and significantly correlated with stalk sugar $\%$ and leaf weight in the combined seasons and leaf length only in the combined season and leaf width in the second and combined seasons. While, sugar \% had positive correlation with leaf weight and in leaf width in the combined season. On the other side, leaf weight had positive correlation with leaf length and leaf width in only the combined season. On the other hand, leaves number had positive correlation with leaf width only in the combined seasons. Also, leaf length had positive correlation with leaf width in the second and combined season. These results are in agreement with those obtained by Audilakshmi et al. (2010)

Table 4. Correlation coefficients of eight traits for Mn4080 sweet sorghum genotype

\begin{tabular}{|c|c|c|c|c|c|c|c|c|}
\hline & $\begin{array}{c}\text { Pant } \\
\text { height }\end{array}$ & $\begin{array}{c}\text { Stalk } \\
\text { diameter }\end{array}$ & $\begin{array}{c}\text { Node } \\
\text { number }\end{array}$ & Sugar\% & $\begin{array}{c}\text { Leaf } \\
\text { Weight }\end{array}$ & $\begin{array}{l}\text { Leaves } \\
\text { number }\end{array}$ & leaf length & $\begin{array}{c}\text { leaf } \\
\text { width }\end{array}$ \\
\hline \multicolumn{9}{|c|}{$1^{\text {st }}$ season } \\
\hline Plant Weight & $0.510^{*}$ & 0.431 & $0.513^{*}$ & $0.508^{*}$ & $0.484^{*}$ & -0.184 & -0.072 & 0.237 \\
\hline Pant height & & 0.120 & 0.389 & 0.348 & 0.418 & -0.042 & -0.327 & -0.256 \\
\hline $\begin{array}{l}\text { Stalk } \\
\text { diameter }\end{array}$ & & & $0.700^{* *}$ & $0.729^{* * *}$ & $0.778^{* * * *}$ & 0.078 & 0.113 & 0.364 \\
\hline Node No & & & & $0.652^{* *}$ & $0.782^{* * *}$ & 0.292 & -0.124 & 0.154 \\
\hline Sugar\% & & & & & $0.645^{* *}$ & 0.181 & -0.088 & 0.239 \\
\hline Leaf weight & & & & & & 0.111 & -0.246 & -0.390 \\
\hline Leaf No. & & & & & & & 0.010 & $0.651^{* *}$ \\
\hline leaf length & & & & & & & & 0.080 \\
\hline \multicolumn{9}{|c|}{$2^{\text {nd }}$ Season } \\
\hline Plant Weight & 0.348 & 0.310 & 0.410 & 0.433 & 0.088 & -0.446 & 0.054 & 0.162 \\
\hline Pant height & & $0.509^{*}$ & $0.574^{*}$ & 0.105 & 0.426 & -0.190 & 0.079 & $0.507^{*}$ \\
\hline $\begin{array}{l}\text { Stalk } \\
\text { diameter }\end{array}$ & & & $0.678^{* *}$ & $0.723^{* * *}$ & $0.694^{* *}$ & 0.168 & 0.103 & $0.622^{* *}$ \\
\hline Node No & & & & 0.467 & 0.218 & -0.038 & 0.096 & $0.695^{* *}$ \\
\hline Sugar\% & & & & & 0.423 & 0.132 & 0.220 & 0.424 \\
\hline Leaf weight & & & & & & -0.016 & 0.151 & 0.235 \\
\hline Leaf No. & & & & & & & 0.094 & 0.067 \\
\hline leaf length & & & & & & & & $0.471^{*}$ \\
\hline \multicolumn{9}{|c|}{ Combined two seasons } \\
\hline Plant Weight & $0.514^{* *}$ & 0.309 & 0.009 & 0.052 & -0.112 & -0.056 & -0.289 & -0.218 \\
\hline Pant height & & 0.293 & 0.093 & -0.110 & 0.083 & 0.063 & -0.320 & -0.154 \\
\hline $\begin{array}{l}\text { Stalk } \\
\text { diameter }\end{array}$ & & & $0.555^{* * *}$ & $0.606^{* * * *}$ & $0.575^{* * * *}$ & 0.080 & 0.118 & 0.382 \\
\hline Node No & & & & $0.692^{* * *}$ & $0.560^{* * *}$ & -0.124 & $0.380^{*}$ & $0.733^{* * *}$ \\
\hline Sugar\% & & & & & $0.627^{* * *}$ & -0.165 & 0.379 & $0.613^{* * *}$ \\
\hline Leaf weight & & & & & & -0.100 & $0.403^{*}$ & $0.612^{* * * *}$ \\
\hline Leaf No. & & & & & & & -0.295 & -0.330 \\
\hline leaf length & & & & & & & & $0.621^{* * *}$ \\
\hline
\end{tabular}

*,**, Significant differences at $5 \%$ and $1 \%$ levels of probability, respectively. 
who indicated that significantly positive correlations show that the changes of two variables are in the same direction, while negative correlations indicate their inverse relationships with each other. For example, stalk yield has significantly positive correlations with plant height, stem diameter and juiciness.

Correlations of nine traits for Sugar drip genotype of sweet sorghum were presented in Table (5).

Differences were observed in the correlation coefficients in terms of the magnitude and direction under different environments. Plant weight had positively and significantly correlated with node number in the first and second season, sugar \% in the second season, leaf weight and leaf width the first season. On the other hand, Plant height had positively and significantly correlated with leaf weight only in the second season. Meanwhile, Stalk diameter had not correlated with the other characters. However, node number had positively and significantly correlated with stalk sugar \% in the second and combined season and leaf weight in the first season and leaves number the second season and leaf length and leaf width only in the combined season. While, sugar $\%$ had positive correlation with leaf length in the combined season. On the other side, leaf weight had positive correlation with leaves number in only the combined season. On the other hand, leaves number had positive correlation with leaf length and leaf width only in the combined season. While, leaf length had no correlation with the other characters in the second and combined season.

Table 5. Correlation coefficients of eight traits for Sugar drip sweet sorghum variety

\begin{tabular}{|c|c|c|c|c|c|c|c|c|}
\hline & $\begin{array}{l}\text { Plant } \\
\text { height }\end{array}$ & $\begin{array}{c}\text { Stalk } \\
\text { diameter }\end{array}$ & $\begin{array}{c}\text { Node } \\
\text { number }\end{array}$ & Sugar\% & $\begin{array}{c}\text { Leaf } \\
\text { Weight }\end{array}$ & $\begin{array}{l}\text { Leaves } \\
\text { number }\end{array}$ & $\begin{array}{c}\text { leaf } \\
\text { length }\end{array}$ & $\begin{array}{c}\text { leaf } \\
\text { width }\end{array}$ \\
\hline \multicolumn{9}{|c|}{$1^{\text {st }}$ season } \\
\hline Plant Weight & -0.104 & 0.080 & $0.792^{* * *}$ & 0.248 & $0.499^{*}$ & -0.443 & 0.059 & $0.605^{* *}$ \\
\hline Pant height & & -0.184 & 0.163 & 0.401 & 0.079 & 0.394 & 0.188 & 0.083 \\
\hline $\begin{array}{l}\text { Stalk } \\
\text { diameter }\end{array}$ & & & 0.127 & -0.339 & 0.394 & -0.419 & 0.044 & -0.029 \\
\hline Node No & & & & 0.411 & $0.526^{*}$ & -0.297 & 0.116 & $0.649^{* *}$ \\
\hline Sugar\% & & & & & -0.012 & -0.377 & 0.223 & 0.388 \\
\hline Leaf weight & & & & & & 0.184 & 0.051 & 0.011 \\
\hline Leaf No. & & & & & & & 0.006 & 0.087 \\
\hline leaf length & & & & & & & & 0.346 \\
\hline \multicolumn{9}{|c|}{$2^{\text {nd }}$ Season } \\
\hline Plant Weight & 0.075 & 0.402 & $0.711^{* * *}$ & $0.929^{* * *}$ & -0.221 & $-0.698^{* *}$ & 0.130 & -0.036 \\
\hline Pant height & & 0.299 & -0.426 & -0.008 & $0.521^{*}$ & 0.045 & -0.406 & -0.286 \\
\hline $\begin{array}{l}\text { Stalk } \\
\text { diameter }\end{array}$ & & & 0.202 & 0.331 & 0.092 & -0.133 & 0.340 & -0.367 \\
\hline Node No & & & & $0.707^{* *}$ & -0.300 & $-0.614^{* *}$ & 0.296 & -0.183 \\
\hline Sugar\% & & & & & -0.115 & -0.014 & -0.437 & $-0.492^{*}$ \\
\hline Leaf weight & & & & & & $-0.826^{* * *}$ & 0.203 & 0.144 \\
\hline Leaf No. & & & & & & & -0.023 & -0.043 \\
\hline leaf length & & & & & & & & 0.014 \\
\hline \multicolumn{9}{|c|}{ Combined over the two seasons } \\
\hline Plant Weight & -0.011 & 0.068 & $0.690^{* * *}$ & $0.650 * * *$ & -0.017 & -0.247 & 0.115 & 0.282 \\
\hline Pant height & & 0.031 & $-0.407^{*}$ & -0.217 & 0.093 & $-0.366^{* *}$ & $-0.486^{* *}$ & -0.280 \\
\hline $\begin{array}{l}\text { Stalk } \\
\text { diameter }\end{array}$ & & & 0.009 & -0.147 & 0.032 & -0.269 & -0.075 & -0.097 \\
\hline Node No & & & & $0.685^{* * *}$ & 0.147 & 0.174 & $0.453 * *$ & $0.347^{*}$ \\
\hline Sugar $\%$ & & & & & 0.180 & 0.187 & $0.335^{*}$ & 0.246 \\
\hline Leaf weight & & & & & & $0.400^{*}$ & 0.150 & 0.003 \\
\hline Leaf No. & & & & & & & $0.638^{* * * *}$ & $0.334^{*}$ \\
\hline leaf length & & & & & & & & 0.241 \\
\hline
\end{tabular}

*, ** Significant differences at $5 \%$ and $1 \%$ levels of probability, respectively. 
These results are in agreement with those obtained by Murray et al. (2008) who observed the similar correlations between most of the interesting traits and production. Makanda et al. (2009) discussed that the negative and highly significant correlation between grain yield and stem biomass suggested that the presence of a yield penalty as biomass is improved.

\section{REFERENCES}

Almodares, A. and D.S.M. Mostafafi .2008. Effects of planting date and time of nitrogen application on yield and sugar content of sweet sorghum. J. Environ. Biol., 27:601605.

Aly, M. H., A. M. Kamel and S. Hassan. 2008. The usage of biofertilizer to minimize the mineral fertilizer for sweet sorghum. Egypt.J. Appl. Sci. 23 (2B): 486-499.

Antonopoulou, G., H.N. Gavala, I.V. Skiadas, K. Angelopoulos and G. Lyberatos. 2008. Biofuels generation from sweet sorghum: fermentative hydrogen production and anaerobic digestion of the remaining biomass. Bioresour. Technol. 99: 110-119.

Audilakshmi, S., A.K. Mall, M. Swarnalatha, and N. Seetharama. 2010. Inheritance of sugar concentration in stalk (Brix), sucrose content, stalk and juice yield in sorghum. Biomass Bioenerg. 34:813-820.

Benlhabib, O., A. Yazar, M., E. Qadir, Louren'o and S.E. Jacobsen. 2014. How can we improve Mediterranean cropping systems. J. Agronomy and Crop Sci. 200: 325332.

CCSC. 2010. Sugar Crops Council. Annual Report, Ministry of Agriculture, Egypt. (In Arabic).

CoStat Ver. 6.4. 2005. Cohort software798 light house Ave. PMB320, Monterey, CA93940, and USA. email: info@cohort.com and Website: http://www.cohort.com/DownloadCoStatPart2.html

Daneshian, J., A. Majid and P. Jonubi. 2002. Evaluating the effect of limited water application dry matter accumulation and growth parameters of soybean. The Seventh Congress of Agronomy and Plant Breeding of Iran.

. Elkhatib, H.A., S.M. Gabr, F.I. Radwan , and R.F. Abo El-Ali . 2009. Differential Effects of Mycorrhizal Fungi and Phosphate Solubilizing Bacteria and Their Potential for Stimulating Plant Growth and Seed Yield of Common Bean . Alex. Sci . Exch. J. 30: 136 - 145.

Gill, M.P.S. and N.S. Dellon. 1995. Phosphorus fertilizer requirements of pearl-millet and sorghum fodders as affected by native fertility of arid brown soil. Indian Journal of Agricultural Research, 15. 29 (1/2): 83-88.

Gomez, K.A. and A.A. Gomez. 1984. Statistical Procedures for Agricultural Research. Book John Willey and Sons Inc. New York.

Hons, F. M., R. F. Moresco, R. P. Wiedenfeld and J.T. Cothren. 1986. Applied nitrogen and phosphorus effects on yield and nutrient uptake by high-energy sorghum produced for grain and biomass Agron. J. 76 :1069-1078
Ismail, A.M.A., S.A. Mohamed, Samia Y. Mohamed and Nahed O. Zohdy. 2007. Response of sorghum to mineral and bio nitrogen. Egypt. J. Agric. Res. 85 (2): 573-586.

Ma, Q., Niknam S.R. and D.W. Turner. 2006. Responses of osmotic adjustment and seed yield of brassica napus and b. junacea to soil water deficit at different growth stages. Aust. J. Agric. Res. 57: 221-226.

Makanda, I., P. Tongoona and J. Derera . 2009. Quantification of genotypic variability for stem sugar accumulation and associated traits in new sweet sorghum varieties. Afr. Crop Sci. Conf. Proc. 9: 391-398.

Malbubi, A. 2004. Wheat and barley production by Barvar-2 phosphorus biofertilizer application Technical Publication No.1. Zist Fannavar Sabz Publications. Tehran.

McLaren J.S., N. Lakey and J. Osborne. 2003. Sorghum as a bioresources platform for future renewable resources. Proc. 57 $7^{\text {th }}$ Corn and Sorghum Res. Conf. CD ROM (Alexandria :American Seed Trade Association).

Mohamed, K.E., H. Ferweez and S.M. Allam. 2006. Effect of $\mathrm{K}$ fertilization on yield and quality of sweet sorghum juice and syrup. Bull. Fac. Agric. Cairo Univ. 57: 401-416.

Murray, S.C., Sharma A., Rooney W.L., Klein P.E., Mullet J.E., Mitchell S.E., Kresovich S. 2008. Genetic improvement of sorghum as a biofuel feedstock: I. QTL for stem sugar and grain nonstructural carbohydrates. Crop Sci. 48:2165-2179.

Osman, M. S. H., H. Ferweez and A. M. H. Osman. 2005. Productivity and technological qualities of juice and syrup of nine sweet sorghum (Sorghum bicolor L. Moench) varieties. Egyptian J. Agric. Res. 83.(3): 1255-1267.

Reddy, N. and Y. Yang. 2005. Biofibers from agricultural by products for industrial applications. Trends in Biotechn. 23: $22-27$

Rego, T.J., V.R. Nagesvara, B. Seeling, G. Pardhasaradhi and D.K. Kumar . 2003. Nutrient balance a guide to improving sorghum and ground based dry land cropping systems in semi-arid tropical India. Field Crops Res. 81: 53-68.

Ritter, K.B., D.R.Jordan, S.C.Chapman, I.D.Godwin, E.S. Mace and C.L. McIntyre . 2008. Identification of QTL for sugarrelated traits in a sweet $\times$ grain sorghum (Sorghum bicolor L. Moench) recombinant inbred population. Mol. Breeding.22.(3):367-384.

Shiringani, A.L., M. Frisch and W. Friedt. 2010. Genetic mapping of QTLs for sugar-related traits in a RIL population of Sorghum bicolor L. Moench. Theor. Appl. Genet. 121(2):323-336.

Soil Survey Staff .1999. Soil Taxonomy. A Basis System of Soil Classification for Making and Interpreting Soil Surveys. Second Edition, Agriculture Handbook, 436. Washington DC): USDA.

Srinivas, G., K. Satish, R. Madhusudhana, R.N. Reddy, S.M. Mohan and N. Seetharama. 2009. Identification of quantitative trait loci for ergonomically important traits and their association with genic-microsatellite markers in sorghum. Theor. Appl. Genet. 118:1439-1454. 
Sumaryono, W. 2006. Kajian komprehensif dan teknologi pengembangan bioetanol sebagai bahan bakar nabati (BBN) Bioenergy Seminar: Prospek Bisnis dan Peluang Investasi. Agency for the Assessment and Application of Technology December 6, Indonesia.

Teshome, Z., A. Fantaye and H. Hagos. 2015. Effect of nitrogen and phosphorus on yield components, yield and sugarcane juice quality parameters of soybean-sugarcane intercropping at Tendaho sugar Factory. Biochem Physiol. 4(151):1-4.
Turhollow, A. F., E. G. Webb and M. E. Downing .2010. Review of sorghum Production Practices: Applications for Bioenergy (America : U.S. epartment Of Energy) Available from http://infoornlgov/sites/publications/files/Pub22854pdf 


\section{الملخص العربي}

\section{استجابة صنفين من الذرة الرفيعة السكرية للتسميل الفوسفاتي المعدني والحيوي \\ نادية كامل الصافي}

أجريت تجربتان حقليتان في المزرعة البحثية - محطة ب.تفوق صنف Sugar drip على صنف Mn- 4080 في وزن الأن

النبات ،و ارتفاع النبات بينما تنوق الصنف الأخير على على

البحوث الزراعية - الصبحية - الأسكندرية خلال موسمي فئمئي

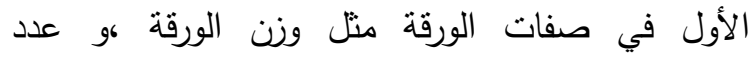

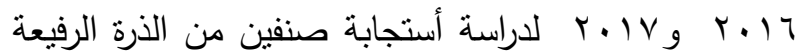

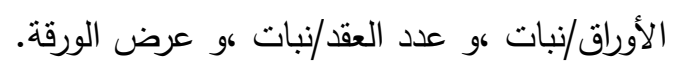

السكرية للنسميد الفوسفاتي المعدني والحيوي.

؟.أختلفت مستويات التسميد الفوسفاتي المعدني في تأثثرها

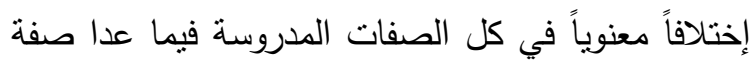

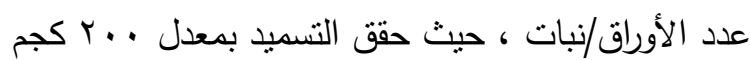
سماد/فدان أعلى قيم للصفات المدروسة بينما أعطت العت

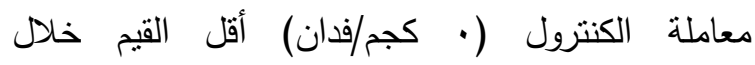

0.وجد إختلافاً معنوياً بين تلقيح حبوب الذرة السكرية

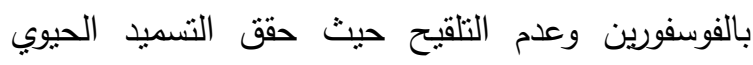
(الفوسفورين) أعلى المتوسطات القيم خلال موسمي

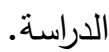

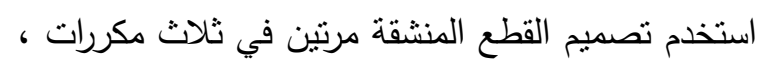

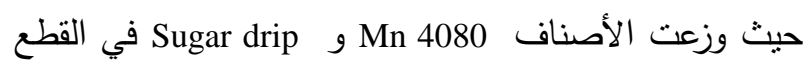
الرئيسية ،ووزعت ثلاثة معدلات من سماد سوبر فوسفات

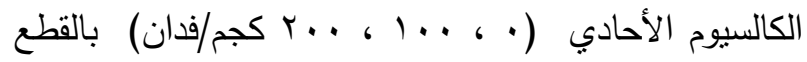

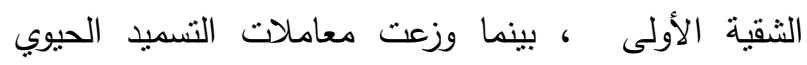

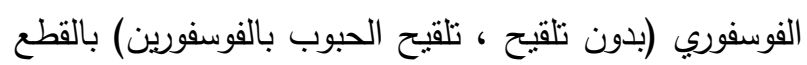
الثقية الثانية. كل قطعة تجريبية اشتملت خمسة خطوط

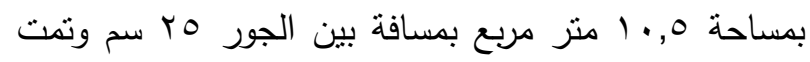

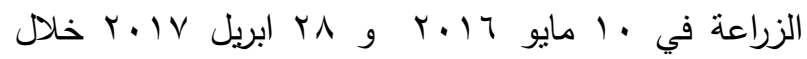
موسمي الزراعة وتم الحصاد في نهاية سبتمبر • مايو

آ. التداخل معنوياً بين معاملات العوامل الثلاثة في بعض الترانة الصفات المدروسة.

V.وجد الارتباط موجب بين صفات النبات وصفات الأوراق

$$
\text { في كل صنف من الذرة السكرية. }
$$

يمكن التوصية بزراعة أحد صنفي الذرة الرفيعة السكرية

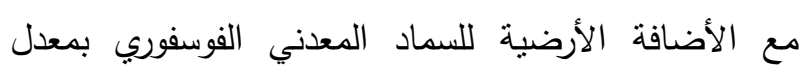

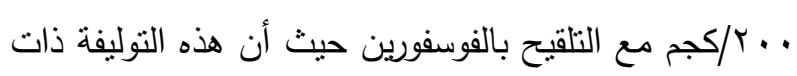
تأثير معنوي على الصفات المدروسة تحت الظروف البيئية

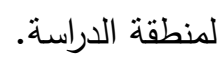

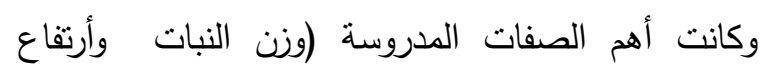

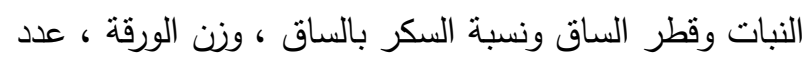
العقد/نبات ، وطول الورقة ،وعرض الورقة). أوضحت النتائج مايلي: ا. وجد ثأثثراً معنوياً لعوامل الدراسة الثلاثة على الصفات الدورسة خلال موسمي الزراعة.

r. وجد اختلافاً معنوياً بين صنفي الذرة السكرية الرفيعة في

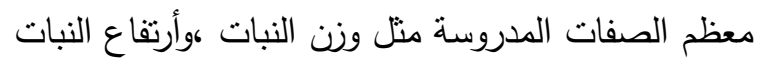
، ووزن الورقة ، وعدد العقد/نبات ،وعرض الورقة فيماعدا قطر الساق ونسبة السكر بالساق وطول الورقة خلال الورفال موسمي الزراعة. 